OPEN ACCESS

Edited by:

Dennis A. Bazylinski,

University of Nevada, Las Vegas,

United States

Reviewed by:

Mustafa Yucel,

Middle East Technical University,

Turkey

Eric D. van Hullebusch,

IHE Delft Institute for Water

Education, Netherlands

*Correspondence:

Renata Guerra-Sá

rguerrasa@gmail.com

Specialty section: This article was submitted to

Microbiological Chemistry

and Geomicrobiology,

a section of the journal

Frontiers in Microbiology

Received: 14 June 2017 Accepted: 22 September 2017 Published: 09 October 2017

Citation:

Barboza NR, Morais MMCA

Queiroz PS, Amorim SS,

Guerra-Sá R and Leão VA (2017)

High Manganese Tolerance and Biooxidation Ability of Serratia marcescens Isolated from Manganese Mine Water in Minas Gerais, Brazil.

Front. Microbiol. 8:1946.

doi: 10.3389/fmicb.2017.01946

\section{High Manganese Tolerance and Biooxidation Ability of Serratia marcescens Isolated from Manganese Mine Water in Minas Gerais, Brazil}

\author{
Natália R. Barboza', Mônica M. C. A. Morais², Pollyana S. Queiroz', Soraya S. Amorim¹, \\ Renata Guerra-Sá ${ }^{*}$ and Versiane A. Leão ${ }^{3}$ \\ ${ }^{1}$ Laboratório de Bioquímica e Biologia Molecular, Departamento de Ciências Biológicas, Instituto de Ciências Exatas e \\ Biológica (NUPEB), Universidade Federal de Ouro Preto, Ouro Preto, Brazil, ${ }^{2}$ Unileste, Ipatinga, Brazil, ${ }^{3}$ Laboratório de \\ Bio\&Hidrometalurgia, Departamento de Engenharia Metalúrgica e de Materiais, Escola de Minas, Universidade Federal de \\ Ouro Preto, Ouro Preto, Brazil
}

Manganese is an important metal for the maintenance of several biological functions, but it can be toxic in high concentrations. One of the main forms of human exposure to metals, such as manganese ( $\mathrm{Mn})$, is the consumption of solar salt contaminated. Mn-tolerant bacteria could be used to decrease the concentration of this metal from contaminated sites through safer environmental-friendly alternative technology in the future. Therefore, this study was undertaken to isolate and identify Mn resistant bacteria from water samples collected from a $\mathrm{Mn}$ mine in the Iron Quadrangle region (Minas Gerais, Brazil). Two bacterial isolates were identified as Serratia marcescens based on morphological, biochemical, 16S rDNA gene sequencing and phylogeny analysis. Maximum resistance of the selected isolates against increasing concentrations of $\mathrm{Mn}(\mathrm{II})$, up to $1200 \mathrm{mg} \mathrm{L}^{-1}$ was determined in solid media. A batch assay was developed to analyze and quantify the $\mathrm{Mn}$ removal capacities of the isolates. Biological Mn removal capacities of over 55\% were detected for both isolates. Whereas that mechanism like biosorption, precipitation and oxidation could be explaining the Mn removal, we seek to give an insight into some of the molecular mechanisms adopted by $S$. marcescens isolates. For this purpose, the following approaches were adopted: leucoberbelin blue I assay, Mn(II) oxidation by cell-free filtrate and electron microscopy and energy-dispersive X-ray spectroscopy analyses. Overall, these results indicate that S. marcescens promotes $\mathrm{Mn}$ removal in an indirect mechanism by the formation of Mn oxides precipitates around the cells, which should be further explored for potential biotechnological applications for water recycling both in hydrometallurgical and mineral processing operations.

Keywords: manganese, bioremediation, Serratia marcescens, manganese oxidation, biooxidation

Abbreviations: BLAST, Basic Local Alignment Search Tool; EDX, energy-dispersive X-ray spectroscopy; gDNA, genomic DNA; HEPES, 4-(2-hydroxyethyl)-1-piperazineethanesulfonic acid; ICP-OES, inductively coupled plasma optical emission spectrometry; LBB, leucoberbelin blue I; MCO, multicopper oxidase; Mn, manganese; MTC, maximum tolerated concentration; SEM, scanning electron microscopy; TEM, transmission electron microscopy. 


\section{INTRODUCTION}

Contaminated mine water remains a major problem worldwide and is associated with severe environmental, socio-economic, and public health impacts. It is mostly characterized by extreme $\mathrm{pH}$ (acidity or alkalinity), high salinity levels, particularly sulfate, $\mathrm{Al}$, sundry toxic metals such as $\mathrm{Fe}, \mathrm{Cd}, \mathrm{Co}, \mathrm{Cu}, \mathrm{Mo}, \mathrm{Zn}, \mathrm{Ni}$, and $\mathrm{V}$, and sometimes even radionuclides (Imtiaz et al., 2015; Beane et al., 2016; Sethurajan et al., 2016). In Brazil and the state of Minas Gerais in particular, mining activities have a long history and have played a major role in both economic development and environmental pollution throughout the country (Instituto Brasileiro de Mineração [IBRAM], 2012; Massante, 2015). Although significant progress has recently been made to address mine water management, environmental pollution due to the disposal of untreated mine water remains a major problem worldwide (Klein et al., 2014). In the specific case of manganese $(\mathrm{Mn})$, several lines of evidence suggest a positive association between environmental exposures, which are common and cumulative in a lifetime, and development of neurodegenerative diseases. Thus, environmental or occupational exposure to $\mathrm{Mn}$ has been implicated in neurodegeneration related to impaired dopaminergic (DAergic), glutamatergic and GABAergic transmission, mitochondrial dysfunction, oxidative stress, and neuroinflammation (Peres et al., 2016).

Normally $\mathrm{Mn}$ is removed by adding some basic chemical to the drainage prior to returning them to the environment. Chemical oxidation could be performed to Mn removal by adding strong oxidizing agents (e.g., potassium permanganate, hypochlorite or ozone) or by aeration (Silva et al., 2010), although they are often expensive and inefficient and produce secondary pollutants such as toxic byproducts (Ehrlich, 1999; Das et al., 2011).

As an alternative, bioremediation by $\mathrm{Mn}$ (II)-oxidizing bacteria has been shown to be a viable strategy for metal removal (Gallard and van Gunten, 2002; Pacini et al., 2005; Mariner et al., 2008; Luan et al., 2012). Biological Mn oxidation can occur by two mechanisms. The first mechanism is the direct mechanism, which is mediated by cellular components such as proteins. This mechanism has been studied for several years and the role of MCO enzymes in the oxidation of $\mathrm{Mn}$ (II) by several species of bacteria has been demonstrated (Brouwers et al., 1999, 2000; Tebo et al., 2004, 2005; Dick et al., 2008; Mayhew et al., 2008; Soldatova et al., 2012; Geszvain et al., 2013; Su et al., 2013). The second mechanism for biological Mn oxidation is the indirect mechanism, which occurs when the metabolism or growth of microorganisms changes the $\mathrm{pH}$ or the redox conditions of the environment or releases metabolic products that can chemically oxidize $\mathrm{Mn}$ (II) to $\mathrm{Mn}$ (III) or $\mathrm{Mn}$ (IV) (Nealson et al., 1988; Tebo et al., 2004; Learman et al., 2011). Richardson et al. (1988) reported that cyanobacteria and algae could promote Mn oxidation by an indirect mechanism. In both cases, $\mathrm{Mn}$ (II) oxidation occurred as a result of environmental modifications of $\mathrm{pH}$ and redox potential (Eh). Hullo et al. (2001) also demonstrated a non-enzymatic Mn(II) oxidation mechanism mediated by Bacillus subtilis. They observed that the oxidation occurred due to the increased $\mathrm{pH}$ promoted by B. subtilis. Although these bacteria contain a spore coat protein,
CotA, that is similar to laccases, this protein did not play any role in the Mn(II) oxidation.

Many bacterial strains that are capable of promoting the oxidation of $\mathrm{Mn}(\mathrm{II})$ to $\mathrm{Mn}(\mathrm{IV})$ by indirect, indirect, or both mechanisms have been identified. Bacillus sp. SG-1, Pseudomonas putida strains $\mathrm{MnB1}$ and GB-1, and Leptothrix discophora strains SS-1 and SP-6, are examples of bacteria that have been extensively studied for bioremediation (Adams and Ghiorse, 1987; van Waasbergen et al., 1996; Hope and Bott, 2004; Tebo et al., 2005; Geszvain et al., 2013). Johnson and Hallberg (2003), Tuffin et al. (2006), and Wang et al. (2011) reported that environmental characteristics such as extreme conditions (e.g., $\mathrm{pH}$, metal concentration, etc.) influence the microbial community composition.

In a previous report, we showed that isolates belonging to the genera Stenotrophomonas, Bacillus, and Lysinibacillus from water samples collected from a Mn mine in the Iron Quadrangle region (Minas Gerais, Brazil) were able to perform Mn(II) oxidation by a non-enzymatic pathway (Barboza et al., 2015), and the isolates used in this present article were also isolated from the same place. Serratia marcescens shows promise for the development of biotechnological and bioremediation processes, for example, in the decolorization of synthetic dyes (Verma and Madamwar, 2003) and the industrial effluent known as black liquor, and the removal of organophosphorus pesticides from soils (Cycon et al.,

TABLE 1 | Phenotypic profiles of the isolates CL11 and CL35.

\begin{tabular}{|c|c|c|}
\hline \multirow[b]{2}{*}{ Conducted test } & \multicolumn{2}{|c|}{ Results } \\
\hline & CL11 & CL35 \\
\hline Colony form & Rod & Rod \\
\hline Gram staining & - & - \\
\hline Catalase & + & + \\
\hline Cytochrome oxidase & - & - \\
\hline ortho-Nitrophenyl galactoside & - & - \\
\hline Arginine decarboxylase & - & - \\
\hline Lysine decarboxylase & + & + \\
\hline Ornithine decarboxylase & + & + \\
\hline $\mathrm{H}_{2} \mathrm{~S}$ & - & - \\
\hline Urease & + & + \\
\hline Voges-Proskauer & + & + \\
\hline L-Phenylalanine & - & - \\
\hline Indole & - & - \\
\hline Citrate & + & + \\
\hline Malonate & - & - \\
\hline Rhamnose & - & - \\
\hline Adonitol & + & + \\
\hline Salicin & + & + \\
\hline Arabinose & - & - \\
\hline Inositol & + & + \\
\hline Sorbitol & - & - \\
\hline Sucrose & + & + \\
\hline Mannitol & + & + \\
\hline Raffinose & - & - \\
\hline
\end{tabular}

Symbols: positive (+); negative (-). 


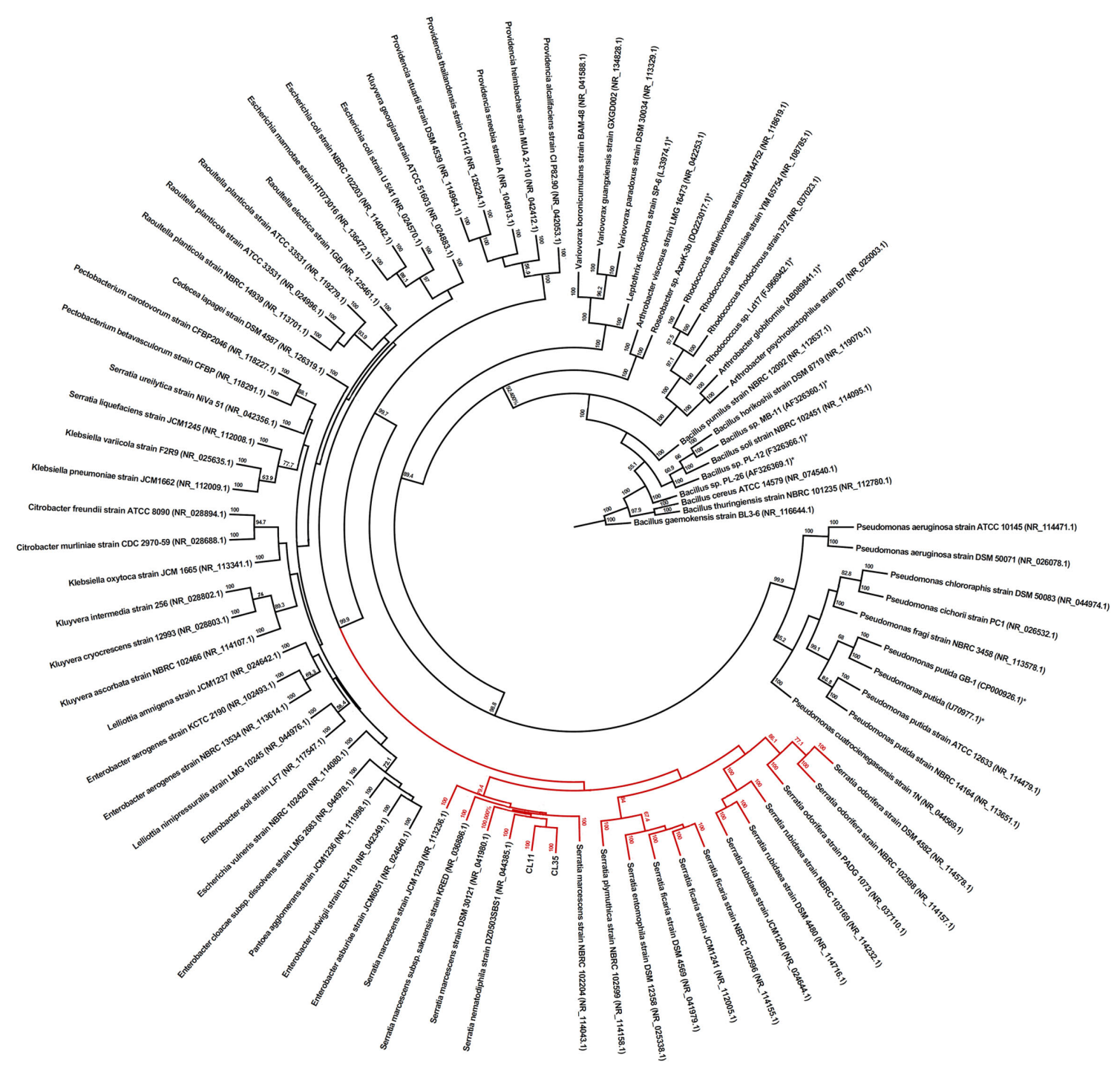

FIGURE 1 | Phylogenetic identification of the CL11 and CL35 isolates. The relationships between the 16S rRNA gene sequences of the isolates and the closest GenBank sequences with the 16S rRNA gene from previously reported Mn(II)-oxidizing bacterial strains (labeled with *) are shown. The GenBank accession numbers of the sequences are shown in brackets. Bootstrap values of $\geq 50 \%$ with 1,000 replicates are indicated at the branch points.

2013). Although the role of $S$. marcescens in iron and Mn oxide formation during pipe corrosion has been investigated (Rajasekar et al., 2007a,b), the potential for $\mathrm{Mn}$ (II) tolerance and removal is not understood. Thus, in this work, we seek to investigate the $\mathrm{Mn}(\mathrm{II})$ tolerance and oxidation capacity of $S$. marcescens isolates with the goal of identifying new isolates with biotechnological potential for Mn removal from mine waters.

\section{MATERIALS AND METHODS}

\section{Sample Collection and Isolation of Mn-Tolerant Strains}

Several samples were obtained from Mn mine water collected from the Iron Quadrangle region (Minas Gerais, Brazil). To select $\mathrm{Mn}$ (II)-tolerant strains, the samples were appropriately diluted and spread on agar plates with $\mathrm{K}$ medium $\left(0.001 \mathrm{~g} \mathrm{~L}^{-1}\right.$ $\mathrm{FeSO}_{4} \cdot 7 \mathrm{H}_{2} \mathrm{O} ; 2 \mathrm{~g} \mathrm{~L}^{-1}$ peptone, $0.5 \mathrm{~g} \mathrm{~L}^{-1}$ yeast extract, and $10 \mathrm{mM}$ HEPES buffer, $\mathrm{pH}$ 7.5) supplemented with $50 \mathrm{mg} \mathrm{L}^{-1}$ $\mathrm{Mn}(\mathrm{II})$ as $\mathrm{MnSO}_{4} \cdot \mathrm{H}_{2} \mathrm{O}$. After 7 days of incubation at $28 \pm 2{ }^{\circ} \mathrm{C}$, two colonies growing on the plates were isolated and selected for the subsequent assays.

\section{Evaluation of $\mathrm{Mn}(\mathrm{II})$ Tolerance}

The isolated bacteria were spread on solid $\mathrm{K}$ medium supplemented with various $\mathrm{Mn}$ (II) concentrations (140-1200 mg $\mathrm{L}^{-1}$ ) to determine their maximum tolerance to this metal. The MTC was defined as the highest concentration of the contaminant for which bacterial growth could be observed after 7 days of incubation at $28 \pm 2^{\circ} \mathrm{C}$. Two strains isolated from 


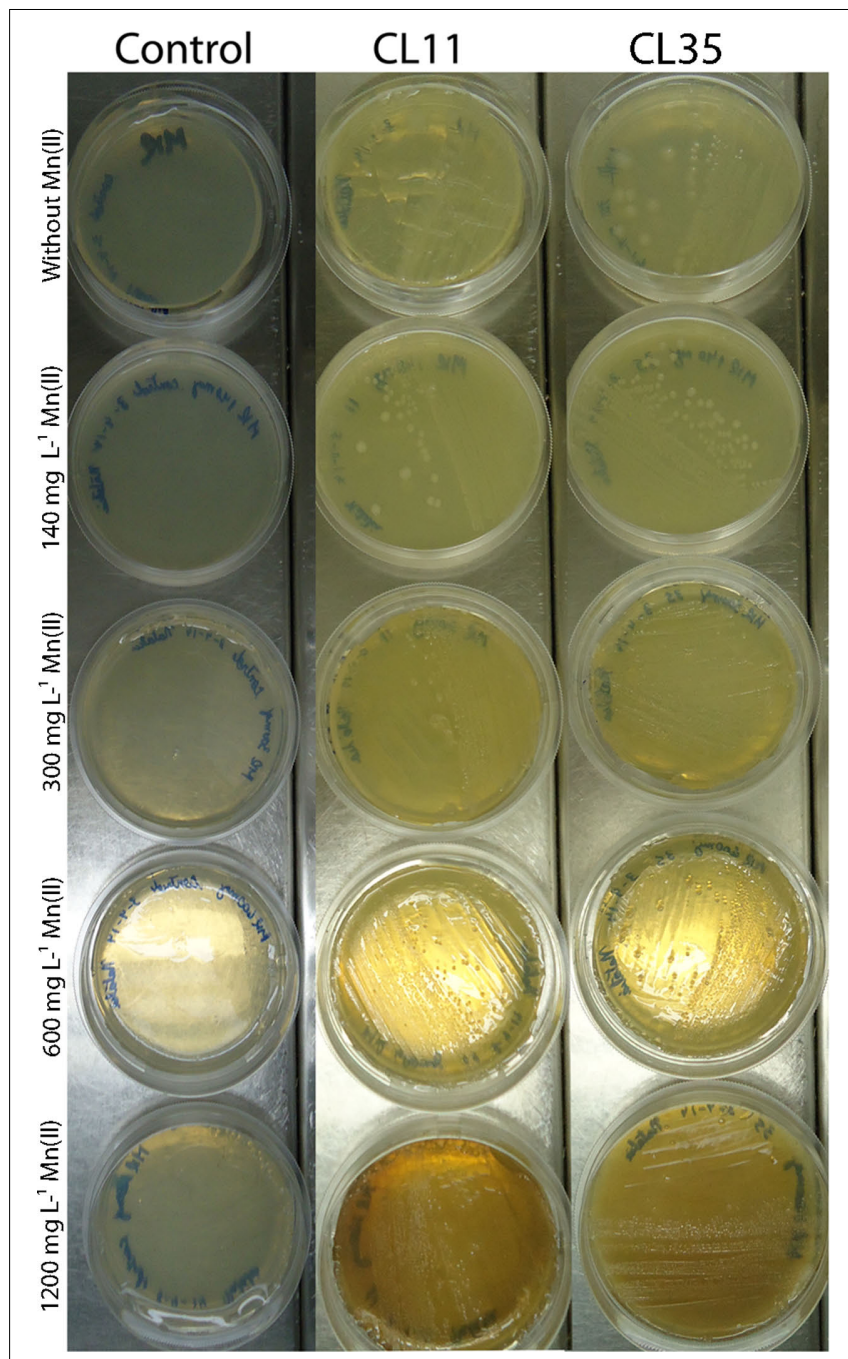

FIGURE 2 | Mn(II) ion tolerance. Isolates CL11 and CL35 were grown on K medium supplemented with various concentrations of $\mathrm{Mn}(\mathrm{II})$ ions. The isolates were cultured at $30^{\circ} \mathrm{C}$ for 2 weeks.

the sediments, named CL11 and CL35 pending their subsequent identification, with the capability to tolerate high $\mathrm{Mn}$ (II) concentrations, were selected, characterized, and identified for further $\mathrm{Mn}(\mathrm{II})$ removal studies.

\section{Characterization and Identification of CL11 and CL35 Isolates}

The isolates were characterized based on their morphology, Gram staining, and oxidase, catalase, and biochemical tests. The metabolic profiles were assessed using the Bactray system (LaborClin, Paraná, Brazil) following the manufacturer's protocol. Subsequently, the results of the biochemical tests were analyzed using the Bactray software. This program utilizes a dataset of the metabolic profiles of many bacteria and compares the experimental results with the dataset.

Identification of the CL11 and CL35 strains through molecular methods was also carried out. For this, the 16S rRNA gene was amplified and sequenced using forward 27F and reverse 1942R primers (Yang et al., 2013). For gDNA extraction, the Wizard Genomic kit (Promega) was used following the manufacturer's recommendations and samples were stored at $4^{\circ} \mathrm{C}$ until use. Prior to gDNA extraction, the isolates were grown in $\mathrm{K}$ medium without $\mathrm{Mn}(\mathrm{II})\left(0.001 \mathrm{~g} \mathrm{~L}^{-1} \mathrm{FeSO}_{4} \cdot 7 \mathrm{H}_{2} \mathrm{O}, 2 \mathrm{~g} \mathrm{~L}^{-1}\right.$ peptone, $0.5 \mathrm{~g} \mathrm{~L}^{-1}$ yeast extract, and $10 \mathrm{mM}$ HEPES buffer at $\mathrm{pH} 7.5$ ) overnight at $30^{\circ} \mathrm{C}$ under constant stirring at $150 \mathrm{rpm}$. The cells were recovered via centrifugation at $14,681 \times g$ for $5 \mathrm{~min}$ and used for gDNA extraction.

PCR amplification was performed in a reaction mixture consisting of Taq buffer $1 \mathrm{X}, 1.5 \mathrm{mM} \mathrm{MgCl}_{2}, 0.2 \mathrm{mM}$ of each deoxynucleotide, $0.2 \mathrm{mM}$ of each primer, $2.5 \mathrm{U}$ Taq DNA polymerase (Thermo Scientific TaqDNA Polymerase, Fermentas), 1 ng DNA template, and water to bring the total volume to $25 \mu \mathrm{L}$. A thermocycling program was carried out using the following protocol: an initial denaturation step $\left(94^{\circ} \mathrm{C}, 5 \mathrm{~min}\right)$, followed by 35 cycles of denaturation $\left(94^{\circ} \mathrm{C}, 45 \mathrm{~s}\right)$, annealing $\left(63^{\circ} \mathrm{C}, 1 \mathrm{~min}\right)$, and extension $\left(72^{\circ} \mathrm{C}, 2 \mathrm{~min}\right)$. A single final extension step $\left(72^{\circ} \mathrm{C}, 20 \mathrm{~min}\right)$ concluded the reaction (Barboza et al., 2015). Purification of the PCR products was carried out as described previously (SambrooK et al., 1989).

The amplicons were sequenced in the forward direction using a BigDye Terminator kit (Applied Biosystems) according to the manufacturer's instructions and analyzed using an automated DNA sequencer (3500 Genetic Analyzer, Applied Biosystems). Triplicates were used to construct the consensus sequences using the ClustalW tool (Aiyar, 2000). The bacterial sequence was used to produce phylogenetic trees constructed using the neighbor-joining method and the Jones-Taylor-Thornton model (Saitou and Nei, 1987) using the consensus sequences. Bootstrap resampling analysis of 1,000 replicates was performed to estimate the confidence levels of the tree topologies and the FigTree 1.4 software was used for phylogenetic analyses. The partial sequences of the $16 \mathrm{~S}$ rRNA gene sequences of the $S$. marcescens isolates were deposited in GenBank under the accession numbers KX444553 (CL11) and KX44455 (CL35).

\section{Mn Removal Assay}

Manganese removal experiments were carried out with synthetic solutions of fresh $\mathrm{K}$ medium supplemented with ca. $45 \mathrm{mg}$ $\mathrm{L}^{-1} \mathrm{Mn}(\mathrm{II})$. The isolate stocks stored at $-80^{\circ} \mathrm{C}$ were grown in

TABLE 2 | Mn(II) ion removal by the CL11 and CL35 isolates and pH variation during small-scale batch experiments over a 1-week period.

\begin{tabular}{lccccc}
\hline & $\begin{array}{c}\text { Mn(II) } \\
\text { removal }\end{array}$ & $\begin{array}{c}\text { Initial Mn(II) } \\
\text { ion concentration }\end{array}$ & $\begin{array}{c}\text { Residual Mn(II) } \\
\text { ion concentration }\end{array}$ & $\begin{array}{c}\text { Initial } \\
\mathbf{p H}\end{array}$ & $\begin{array}{c}\text { Final } \\
\mathbf{p H}\end{array}$ \\
\hline Control & 0\% & $44.23 \mathrm{mg} \mathrm{L}^{-1}$ & $45.13 \mathrm{mg} \mathrm{L}^{-1}$ & 7.52 & 6.89 \\
CL11 & $66.42 \% * \#$ & $44.89 \mathrm{mg} \mathrm{L}^{-1}$ & $15.07 \mathrm{mg} \mathrm{L}^{-1}$ & 7.38 & 8.08 \\
CL35 & $56.37 \% *$ & $42.99 \mathrm{mg} \mathrm{L}^{-1}$ & $18.74 \mathrm{mg} \mathrm{L}^{-1}$ & 7.38 & 7.94 \\
pH 7.5 & $7.05 \%$ & $40.82 \mathrm{mg} \mathrm{L}^{-1}$ & $37.93 \mathrm{mg} \mathrm{L}^{-1}$ & 7.54 & 7.43 \\
pH 8.0 & $50.86 \%$ & $42.64 \mathrm{mg} \mathrm{L}^{-1}$ & $20.95 \mathrm{mg} \mathrm{L}^{-1}$ & 8.03 & 8.04 \\
pH 8.2 & $48.77 \%$ & $38.75 \mathrm{mg} \mathrm{L}^{-1}$ & $19.85 \mathrm{mg} \mathrm{L}^{-1}$ & 8.23 & 8.16
\end{tabular}

*Statistically different from control and $\mathrm{pH}$ 7.5. \#Statistically different from $\mathrm{pH} 8.0$ and $\mathrm{pH} 8.2$. 

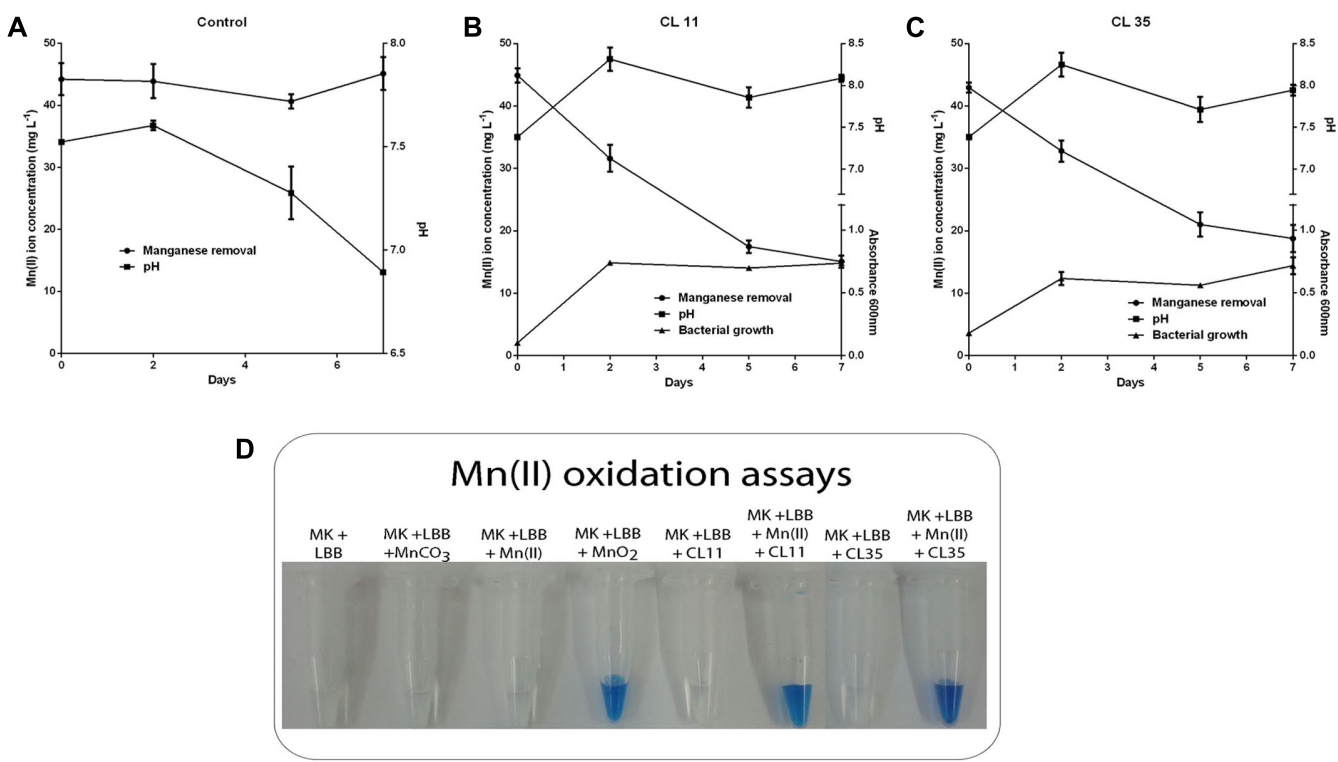

FIGURE 3 | Decay of manganese concentration during manganese removal assay by the CL11 and CL35 isolates and qualitative determination of Mn(II) oxidation. The time course plots for Mn(II) removal, pH changes, and cell growth (where applicable) for (A) the control experiments and (B) the CL11 and (C) CL35 isolates. The cells were grown in $\mathrm{K}$ medium for 1 week. (D) For the qualitative determination of Mn(II) oxidation, $0.04 \%$ of LBB reagent was added to the strains grown in $\mathrm{K}$ medium with $45 \mathrm{mg} \mathrm{L}^{-1} \mathrm{Mn}(\mathrm{II})$ for 1 week. The error bars indicates the standard deviation of the biological triplicate.

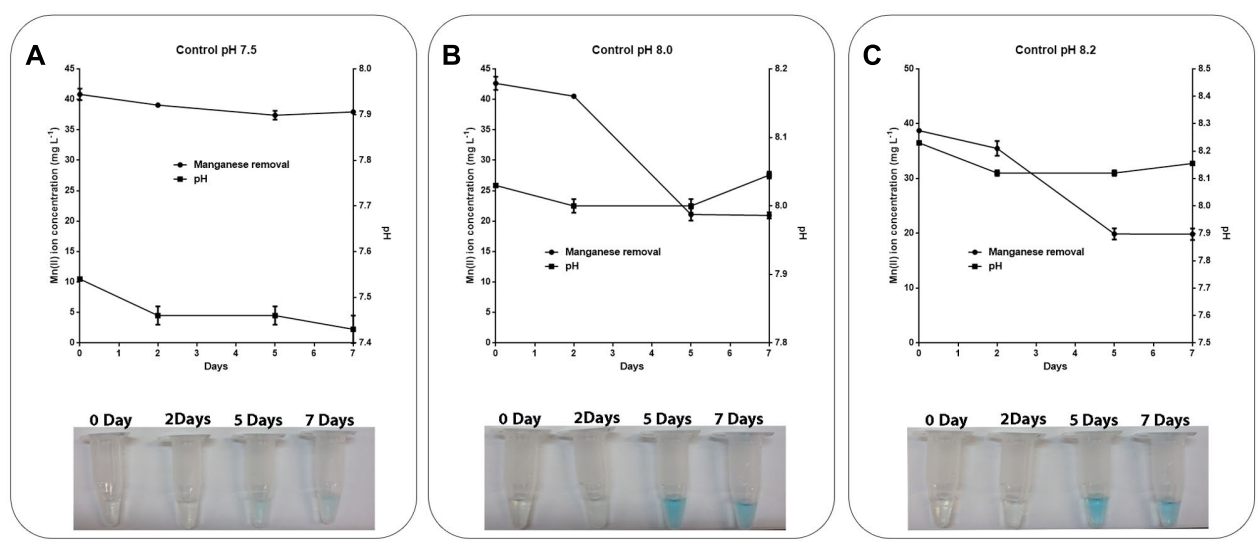

FIGURE 4 | Role of $\mathrm{pH}$ in manganese oxidation during manganese removal assay. $\mathrm{K}$ medium supplemented with $45 \mathrm{mg} \mathrm{L}^{-1} \mathrm{Mn}$ (II) at $\mathrm{pH}$ values of (A) 7.5 , (B) 8.0 , or (C) 8.2 was maintained at $30^{\circ} \mathrm{C}$ under constant stirring $(150 \mathrm{rpm})$ for 7 days. The samples were collected and manganese removal was determined by inductively coupled plasma optical emission spectrometry. Manganese oxidation was detected by the addition of $0.04 \%$ LBB reagent to the samples. The error bars indicates the standard deviation of the technical triplicate.

$100 \mathrm{~mL}$ of $\mathrm{K}$ medium without $\mathrm{Mn}(\mathrm{II})$ at $30^{\circ} \mathrm{C}$ under constant stirring $(150 \mathrm{rpm})$ for $24 \mathrm{~h}$. Then, this culture was transferred to 250 -mL flasks containing $90 \mathrm{~mL}$ of fresh $\mathrm{K}$ medium without $\mathrm{Mn}(\mathrm{II})$. Subsequently, $10 \mathrm{~mL}$ of the culture (with an approximate optical density of 1.0 at $600 \mathrm{~nm}$ ) was transferred to $90 \mathrm{~mL}$ of fresh $\mathrm{K}$ medium with ca. $45 \mathrm{mg} \mathrm{L}^{-1} \mathrm{Mn}(\mathrm{II})$, and the flasks were incubated at $30^{\circ} \mathrm{C}$ under constant stirring $(150 \mathrm{rpm})$ for 7 days. Samples were collected periodically to measure the $\mathrm{Mn}$ (II) concentration (ICP-OES, Varian 725), $\mathrm{pH}$, and bacterial growth (via the optical density at $600 \mathrm{~nm}$ using a Hitachi $2800 \mathrm{~A}$ series spectrophotometer). The Mn quantification was enhanced as previously described by Barboza et al. (2015): an aliquot of $4 \mathrm{ml}$ of each sample was centrifuged for $15 \mathrm{~min}$ at $14,681 \times \mathrm{g}$ and then filtered through a $0.22-\mu \mathrm{m}$ membrane. The filtrate was diluted ten times in distilled water, and acidified with $\mathrm{HCl}$ (1:1) solution. Mn removal from the culture medium was measured by the decay of $\mathrm{Mn}$ concentration in the samples, via ICP-OES assay. Briefly, the ICP-OES analyzes were performed using the following parameters: accuracy of 5\%, detection limit of $0.001 \mathrm{mg} \mathrm{L}^{-1}$ and limit of quantification of $0.01 \mathrm{mg} \mathrm{L}^{-1}$. For the equipment calibration, after the initial adjustments, which comprise the optical stabilization and calibration of the spectral 

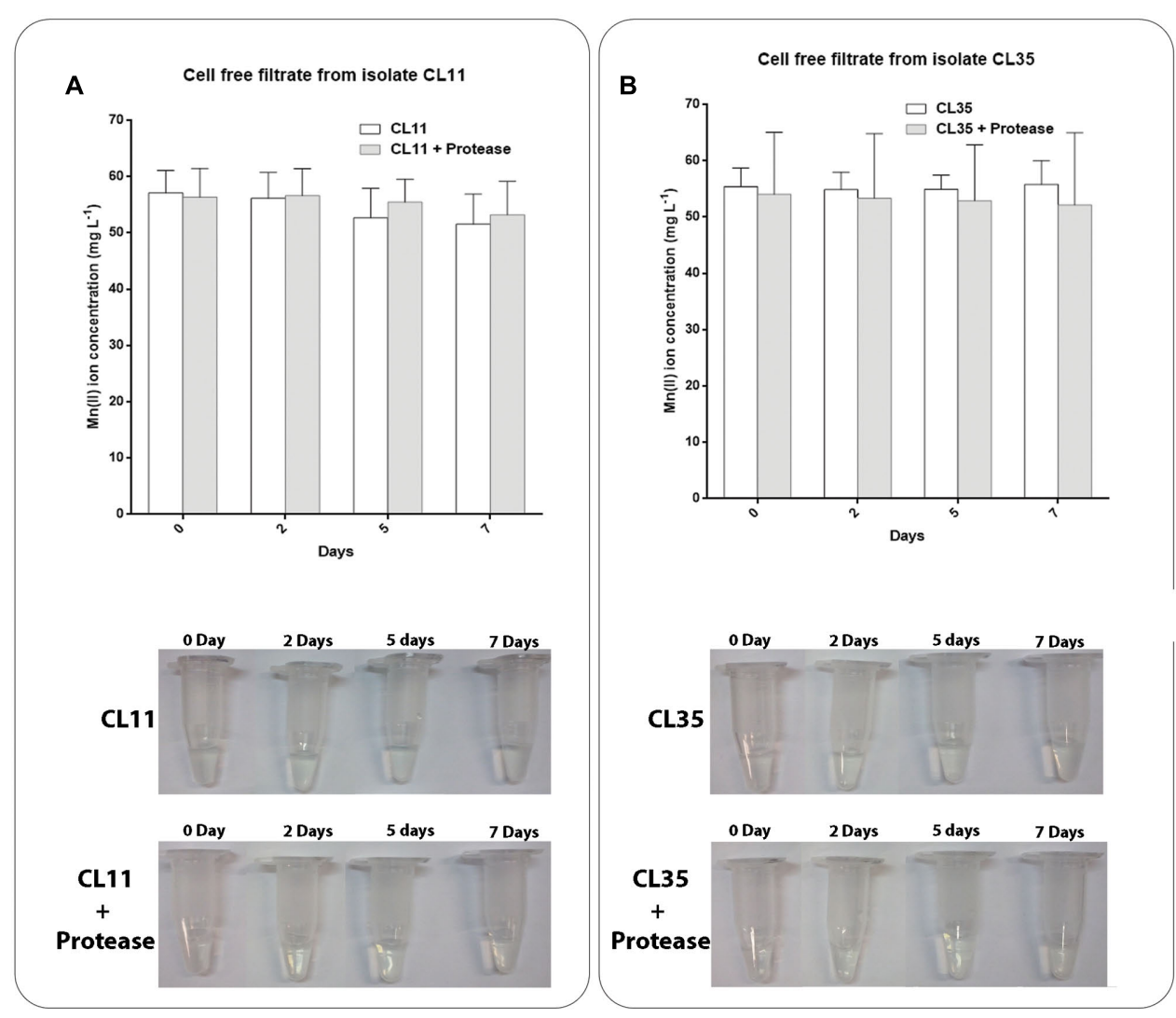

FIGURE 5 | Decay of manganese concentration during manganese removal assay and Mn(II) oxidation in cell-free filtrates of (A) CL11 and (B) CL35 under standard conditions or after the addition of proteinase $\mathrm{K}$. The isolates were grown in $\mathrm{K}$ medium and the supernatant was recovered to evaluate the oxidation of Mn as described in section "Materials and Methods." Samples were collected periodically and manganese removal was determined by ICP-OES. The presence of manganese oxide was monitored by the addition of LBB to the samples. The error bars indicates the standard deviation of the biological triplicate.

lines (Mn wavelength: $257.610 \mathrm{~nm}$ ), the analytical calibration curve was constructed which comprises the points of the curve (0; 2.5; 5.0; and $10 \mathrm{mg} \mathrm{L}^{-1}$ of $\left.\mathrm{Mn}\right)$. Then, the external standard was analyzed ( $5 \mathrm{mg} \mathrm{L}^{-1}$ of $\mathrm{Mn}$ ) and subsequently the analysis of the samples was started. All measurements were made in triplicate and the ICP-OES was configured to report the average value, respecting the accuracy of the $5 \%$ method. Control flasks (abiotic experiments) with the $\mathrm{pH}$ adjusted to $7.5,8.0$, or 8.2 were maintained under similar conditions, and bacterial growth was prevented by adding Nipagin (0.14\%)/Nipazol $(0.1 \%)$. The experiments were performed in triplicate. Results were compared using the ANOVA (ONE-WAY) (Turkey test) and were considered statistically significant at $p<0.0001$. The software used was GraphPad Prism.

\section{Mn(II) Oxidation by Cell-Free Filtrate}

The cell-free filtrates were prepared as described previously (Learman et al., 2011). The cell-free filtrate The cell free filtrate of each sample was divided into two equal parts, one of which was treated with proteinase $\mathrm{K}\left(100 \mu \mathrm{g} \mathrm{mL}^{-1}\right.$, Promega) at $37^{\circ} \mathrm{C}$ for $3 \mathrm{~h}$ before adding of, approximately $45 \mathrm{mg} \mathrm{L}^{-1}$ of $\mathrm{Mn}$ (II). The flasks (i.e., with or without proteinase $\mathrm{K}$ ) were incubated at $37^{\circ} \mathrm{C}$ and $150 \mathrm{rpm}$ for 7 days. Samples were collected periodically to evaluate the Mn removal and Mn oxidation, by ICP-OES and leucoberbelin blue I dye (LBB, Sigma-Aldrich, United States) assay, respectively.

\section{Mn(II) Oxidation Assays}

To assess whether $\mathrm{Mn}$ removal occurred via Mn oxidation, $0.1 \mathrm{~mL}$ samples of the cultured CL11 and CL35 isolates grown with ca. $45 \mathrm{mg} \mathrm{L}^{-1} \mathrm{Mn}$ (II) for a week were mixed with $0.5 \mathrm{~mL}$ of $0.04 \%$ LBB in $45 \mathrm{mM}$ acetic acid (Krumbein and Altmann, 1973). As negative controls, $\mathrm{K}$ medium with or without $45 \mathrm{mg} \mathrm{L}^{-1}$ $\mathrm{Mn}(\mathrm{II})$ or with only the isolate were mixed with LBB and a Mn carbonate $\left(\mathrm{MnCO}_{3}\right)$ solution. As a positive control, $\mathrm{K}$ medium with $\mathrm{Mn}$ oxide $\left(\mathrm{MnO}_{2}\right)$ was used.

\section{Electron Microscopy and Energy-Dispersive X-Ray Spectroscopy (EDX) Analyses}

The CL11 and CL35 isolates cultured in liquid K medium with ca. $45 \mathrm{mg} \mathrm{L}^{-1} \mathrm{Mn}$ (II) for 7 days, as previously described, were analyzed via TEM and SEM. SEM/EDX assays were carried out using an FEI Quanta 200 FEG, and TEM/EDX assays were performed using a Tecnai G2 12 Spirit Biotwin FEI-120 kV and 


\section{SEM TEM}

A
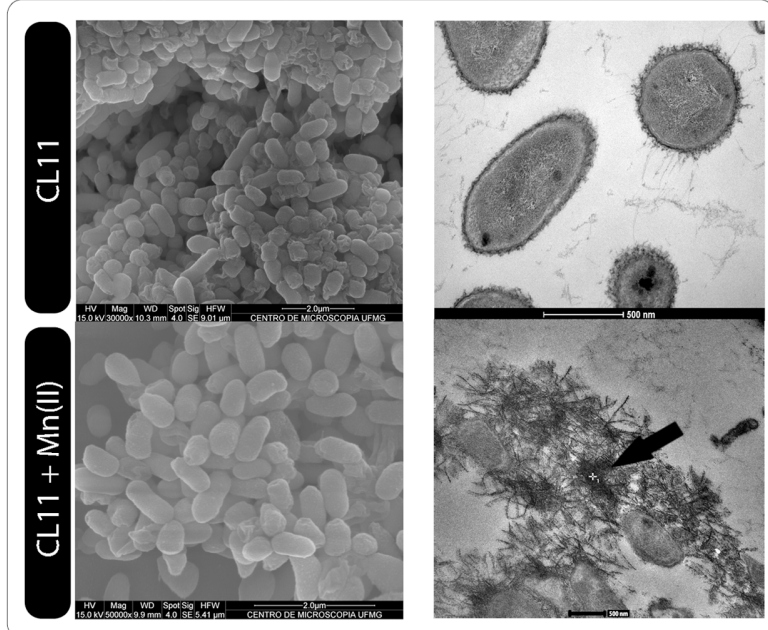

B
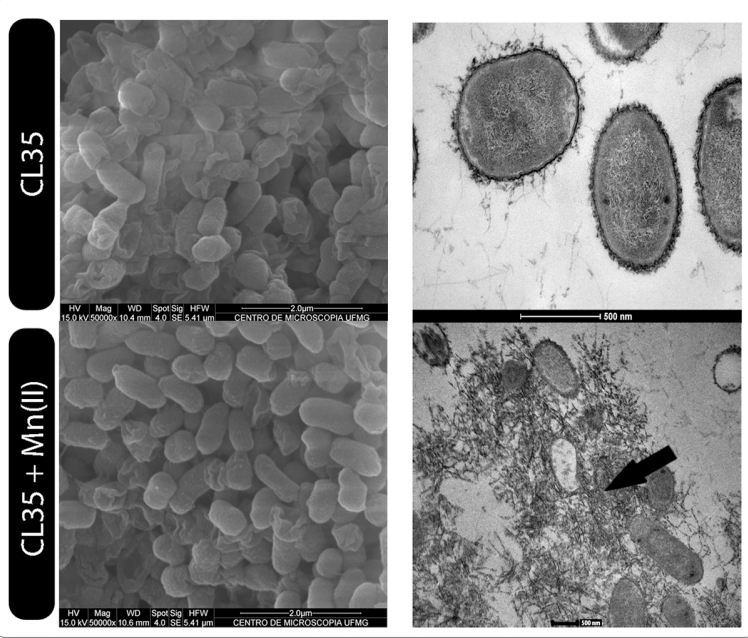

FIGURE 6 | Electron microscopy of the (A) CL11 and (B) CL35 isolates. SEM and TEM images of the isolates cultured in $\mathrm{K}$ medium in the presence or absence of $45 \mathrm{mg} \mathrm{L}^{-1} \mathrm{Mn}(\mathrm{II})$ for 7 days.

a Tecnai G2 20 SuperTwin FEI-200 kV. Electron microscopy were carried out in the Center of Microscopy at the Universidade Federal de Minas Gerais, Belo Horizonte, MG, Brazil.

\section{RESULTS}

\section{Phenotypic and Phylogenetic Analysis of the Isolates}

Both of the isolates were rod-shaped, non-pigmented, Gramnegative, and catalase and cytochrome oxidase negative (Table 1). The biochemical test results were analyzed using the Bactray software, and both isolates were identified as S. marcescens with a confidence level of $99.97 \%$. To confirm this identification, we also used a molecular approach for phylogenetic identification. The 16S rRNA genes from both isolates were amplified, sequenced, and found to exhibit 91.5 and $81.17 \%$ of $16 \mathrm{~S}$ RNA coverage compared with the $S$. marcescens sequences deposited in the database for CL11 (accession number KX444553) and CL35 (accession number KX444554), respectively. The BLAST (Altschul et al., 1990) was used to search for similar sequences from GenBank. Furthermore, the 16S rRNA sequences of several well-known $\mathrm{Mn}$ (II)-oxidizing bacteria were included in the phylogenetic study. We found that the isolates CL11 and CL35 were closely clustered with the genus Serratia, primarily with S. marcescens (Figure 1). Because the phenotypic and phylogenetic characterizations showed the same results, we identified both isolates as $S$. marcescens.

\section{Evaluation of $\mathrm{Mn}$ (II) Tolerance}

Initially, the isolates were grown in solid $\mathrm{K}$ medium containing different $\mathrm{Mn}$ (II) ion concentrations (140, 300, 600, and $1200 \mathrm{mg} \mathrm{L}^{-1}$ ). The capability for $\mathrm{Mn}$ (II) removal was verified by the development of brown color in the colonies or in culture medium. As shown in Figure 2, both the Cl11 isolate and the CL35 isolate were able to grow at the Mn concentrations used.

\section{S. marcescens Promotes Mn Removal by Mn(II) Oxidation}

To investigate the further use of the wild $S$. marcescens isolates in bioremediation approaches, batch Mn removal experiments were performed. The ability to $\mathrm{Mn}$ removal of the isolates was tested with respect to incubation time ( 0 min to 7 days) as well as the initial ca. $45 \mathrm{mg} \mathrm{L}^{-1} \mathrm{Mn}$ (II) concentration and $\mathrm{pH}$ conditions. We found that isolates CL11 and CL35 were able to remove $56.37-66.42 \%$ of the $\mathrm{Mn}$ (II) from a synthetic solution containing approximately $45 \mathrm{mg} \mathrm{L}^{-1} \mathrm{Mn}$ (II) after 1 week. We also observed an increase in $\mathrm{pH}$ (7.38 to 8.0; Table 2 and Figures 3B,C). In the abiotic control experiment, no $\mathrm{Mn}$ removal was observed from the culture medium, and the $\mathrm{pH}$ decreased from 7.52 to 6.89 .

As the $\mathrm{pH}$ in the abiotic experiments decreased to 6.89 and the $\mathrm{pH}$ of the media containing the isolates increased to approximately 8.0, abiotic experiments were performed using $\mathrm{K}$ medium with the $\mathrm{pH}$ adjusted to $7.5,8.0$, or 8.2 (Figure 4). It was observed that at $\mathrm{pH} 8.0$ or above, the $\mathrm{Mn}$ removal reached $50 \%$ efficiency (Figures 4B,C) and the $\mathrm{pH}$ remained constant during the experiments (Figure 4). The addition of the LBB reagent in samples collected periodically also demonstrated Mn oxidation at $\mathrm{pH} 8.0$ or above (Figure 4 ).

$\mathrm{Mn}(\mathrm{II})$ oxidation assays were also performed using cell-free filtrates in either the presence or absence of proteinase $\mathrm{K}$ to assess whether any extracellular proteins were responsible for the Mn oxidation. We did not observe Mn removal or oxidation by the cell-free filtrates from the isolates CL11 (Figure 5A) or CL35 (Figure 5B) in either the presence or absence of the protease. These results indicate that no extracellular proteins were involved in the Mn oxidation by the isolates studied.

\section{SEM/EDX and TEM/EDX Analyses}

Scanning electron microscopy and TEM analyses revealed no aggregates either on cell membrane of the isolates or within the cells after 7 days of culture (Figure 6). However, when the isolates 


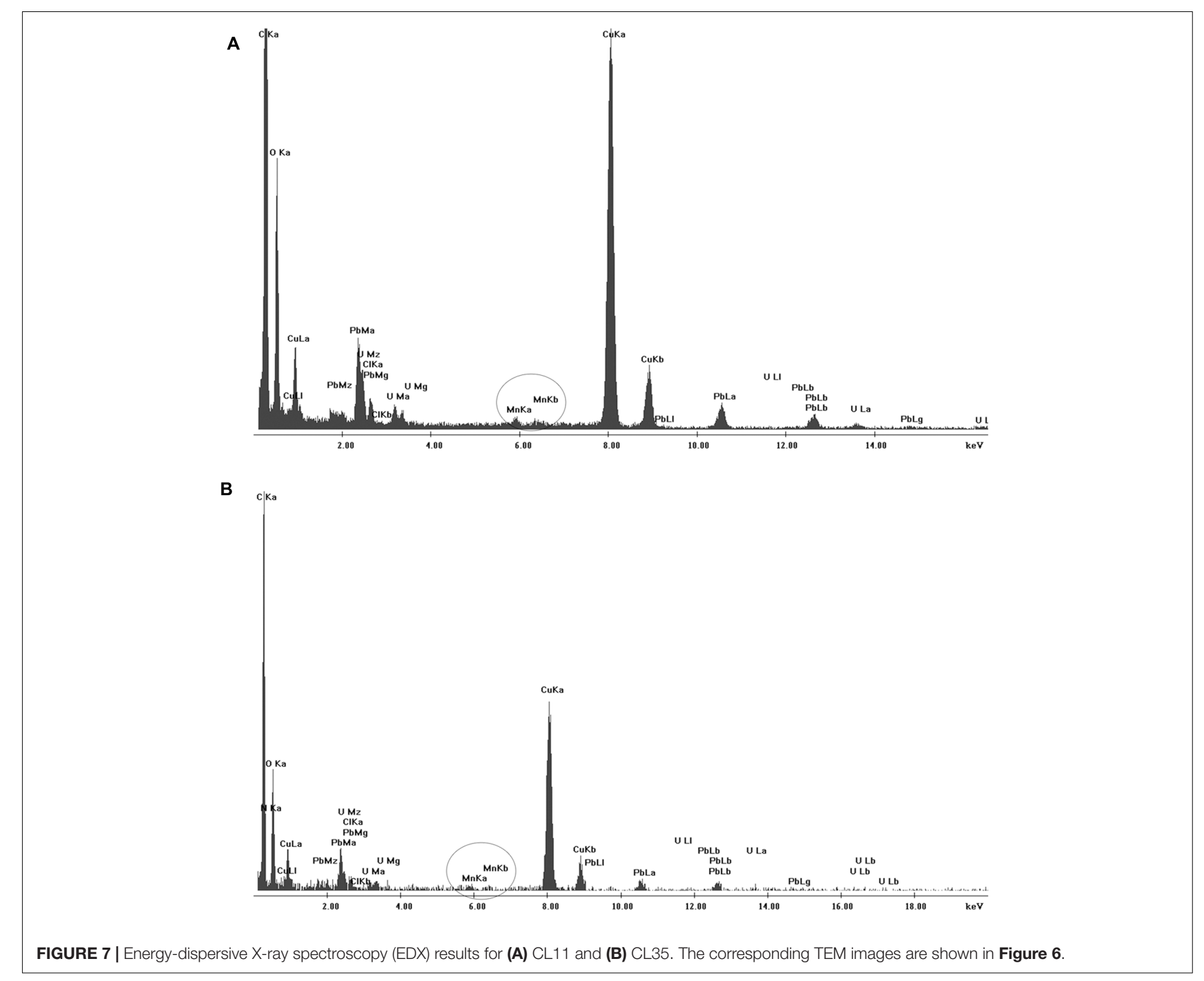

were grown in the presence of $\mathrm{Mn}$ (II) ions, we observed the extracellular precipitation of a Mn-containing mineral phase, as revealed by the EDX spectra (Figure 6, indicated by arrows, and Figure 7).

\section{DISCUSSION}

The Mn could be found in several oxidation states depending on the redox conditions of the environment and the bacteria play an important role in the Mn geochemical cycle. L. discophora (strains SS1 and SP-6), P. putida, and Bacillus sp. SG-1 are the most studied species related to $\mathrm{Mn}$ (II) oxidation (Barboza et al., 2016). Similarly, S. marcescens isolates were found as part of the microbial community at a Mn mine in the Iron Quadrangle region (Minas Gerais, Brazil) (Barboza et al., 2015).

In this study, we have shown that these isolates are capable of promoting Mn oxidation, at least under laboratory conditions, and that this oxidation probably does not involve extracellular enzymes and is instead due to interaction with a metabolic product from bacteria (e.g., hydroxy acids) or a bacterial cell component.

The role of $S$. marcescens in bioprocesses such as the decolorization of synthetic dyes (Verma and Madamwar, 2003) and the industrial effluent known as black liquor (Chandra et al., 2011) and the bioremediation of environments contaminated with pesticides or uranium (Abo-Amer, 2011; Kumar et al., 2011), was described, however, this is the first study showing the potential of $S$. marcescens in Mn bioremediation processes. Both of the isolates used in this study (CL11 and CL35) were able to grow at $\mathrm{Mn}$ (II) concentrations of up to $1200 \mathrm{mg} \mathrm{L}^{-1}$ (Figure 2) and remove more than 55\% of $\mathrm{Mn}$ (II) from the culture medium in 7 days (Table 2 and Figures 3B,C). Several studies have shown that different bacteria species tolerate and are able to remove $\mathrm{Mn}$, however, in these work smaller $\mathrm{Mn}$ concentrations were used to evaluate the tolerance of bacteria against this metal (Xuezheng et al., 2008; Joshi and Modi, 2013; Barboza et al., 2016; 
Tang et al., 2016). Despite this, our research group identified other bacteria species, such as Bacillus sp., Stenotrophomonas sp., and Lysinibacillus sp. isolated from the same mine where the strains CL11 and CL35 were obtained, suggesting that the ambient may have influence on the high Mn tolerances of these microorganisms (Barboza et al., 2015).

To investigate which mechanism was used by the isolates CL11 and CL35 to promote Mn removal, control experiments were performed at $\mathrm{pH} 7.5,8.0$, and 8.2 , since a $\mathrm{pH}$ value of approximately 8.0 was reached in the Mn-removal experiments with the isolates. It was observed that at $\mathrm{pH} 8.0$ and 8.2 , the Mn was removed by oxidation (Figures 4B,C) with an efficiency of $50 \%$ (Table 2). Despite many attempts to buffer the culture medium with HEPES, a $\mathrm{pH}$ increase was also observed during $\mathrm{Mn}$ removal by the isolates (Table 2 and Figures 3B,C), whereas both negligible $\mathrm{Mn}$ removal and no increase in the $\mathrm{pH}$ were observed in the abiotic experiments at $\mathrm{pH} 7.5$ or below (Figures $3 \mathbf{A}, \mathbf{4 A}$ ). Therefore, we suggested that bacterial growth induces changes in the $\mathrm{pH}$ and favors the chemical removal of $\mathrm{Mn}(\mathrm{II})$. Several published finding reinforce that $\mathrm{pH}$ is one of the major factors affecting manganese oxidation (Bamforth et al., 2006; Burger et al., 2008; Divekar, 2010; Silva et al., 2010, 2012). Under our conditions, the Mn oxidation was confirmed by addition of the LBB reagent (Figure 3D).

We also tested if $S$. marcescens, under the growth conditions used in this work, would be capable of inducing the secretion of proteins that alter the environmental conditions and thus favor the oxidation of the $\mathrm{Mn}$ (II) to $\mathrm{Mn}$ (III) or $\mathrm{Mn}$ (IV). As the $\mathrm{Mn}$ removal rate was not affected by proteinase $\mathrm{K}$ treatment of the cell-free filtrate, we infer that the Mn removal/oxidation was not dependent on the presence of a protein in the culture medium (Figure 5). Together, these results reinforce the hypothesis that the Mn removal mediated by the $S$. marcescens isolates mainly occurs via a mechanism that does not involve extracellular enzymes, although we cannot exclude the participation of intracellular proteins.

Electron microscopy did not reveal any Mn precipitates on the cell membrane or inside the cells, but EDX scanning revealed Mn-containing precipitates around the cells produced by both isolates only in the presence of $\mathrm{Mn}$ (II) ions (Figure 6, indicated by the arrow). It is known that typically, biogenic Mn oxides are poorly crystalline and Mn oxides are deposited around bacterial cells. For instance, Mn oxides were found to be deposited around the exosporium of Bacillus sp. SG-1 (Nealson et al., 1988; Dick et al., 2008; Soldatova et al., 2012), whereas the oxides were found around the sheaths in L. discophora (Emerson and Ghiorse, 1992). Miyata et al. (2007) observed similar structures in ultrathin

\section{REFERENCES}

Abo-Amer, A. (2011). Biodegradation of diazinon by Serratia marcescens DI101 and its use in bioremediation of contaminated environment. J. Microbiol. Biotechnol. 21, 71-80. doi: 10.4014/jmb.1007.07024

Adams, L. F., and Ghiorse, W. C. (1987). Characterization of extracellular $\mathrm{Mn}^{2+}$. oxidizing activity and isolation of an $\mathrm{Mn}^{2+}$-oxidizing protein from Leptothrix discophora SS-1. J. Bacteriol. 169, 1279-1285. doi: 10.1128/jb.169.3.1279-1285. 1987 sections of Mn microconcretions, which we also observed using SEM and TEM microscopy.

\section{CONCLUSION}

Concern for $\mathrm{Mn}(\mathrm{II})$ contamination has assumed great importance as it poses potential hazards to the environment, wildlife, and human health. In this study, we confirmed the presence of two Mn-tolerant $S$. marcescens isolates in mine water. The CL11 and CL35 isolates were found to be tolerant to high concentrations of $\mathrm{Mn}$ (II) and possess good $\mathrm{Mn}$ (II) oxidation capacities. This ability of the S. marcescens isolates makes them suitable candidates for the treatment of water contaminated with $\mathrm{Mn}$ (II). However, further studies, such as into their interactions with the water environment, are still needed before the application of these strains in field-scale biooxidation.

\section{AUTHOR CONTRIBUTIONS}

NB carried out the experiments into manganese removal, biooxidation, molecular characterization of the strains, and SEM/EDX and TEM/EDX analyses. NB, RG-S, and VL designed the research and wrote the manuscript. MM, SA, and PQ performed the isolation and biochemical characterization of the isolates. All authors participated effectively in the analyzes and discussions of the results as well as in the writing of the article.

\section{FUNDING}

This study was sponsored by the Conselho Nacional de Pesquisa e Desenvolvimento $(\mathrm{CNPq})$, Fundação de Amparo à Pesquisa do Estado de Minas Gerais (FAPEMIG), Financiadora de Estudos e Projetos (FINEP), company Vale, and Universidade Federal de Ouro Preto.

\section{ACKNOWLEDGMENTS}

The authors would also like to acknowledge the Center of Microscopy at the Universidade Federal de Minas Gerais (http://www.microscopia.ufmg.br) for providing the equipment and technical support for the experiments involving electron microscopy. The authors would especially like to thank Kinulpe Honorato-Sampaio for his technical assistance.

Aiyar, A. (2000). The use of CLUSTAL W and CLUSTAL X for multiple sequence alignment. Methods Mol. Biol. 132, 221-241.

Altschul, S. F., Gish, W., Miller, W., Myers, E. W., and Lipman, D. J. (1990). Basic local alignment search tool. J. Mol. Biol. 215, 403-410. doi: 10.1016/S00222836(05)80360-2

Bamforth, S. M., Manning, D. A. C., Singleton, I., Younger, P. L., and Johnson, K. L. (2006). Manganese removal from mine waters - investigating the occurrence and importance of manganese carbonates. Appl. Geochem. 21, 1274-1287. doi: 10.1016/j.apgeochem.2006.06.004 
Barboza, N. R., Amorim, S. S., Santos, P. A., Reis, F. D., Cordeiro, M. M., Guerra$\mathrm{Sa}, \mathrm{R}$., et al. (2015). Indirect manganese removal by Stenotrophomonas sp. and Lysinibacillus sp. isolated from Brazilian mine water. BioMed Res. Int. 2015:925972. doi: 10.1155/2015/925972

Barboza, N. R., Guerra de Sa, R., and Leão, V. A. (2016). Mechanisms of manganese bioremediation by microbes: an overview. J. Chem. Technol. Biotechnol. 91, 2733-2739. doi: 10.1002/jctb.4997

Beane, S. J., Comber, S. D., Rieuwerts, J., and Long, P. (2016). Abandoned metal mines and their impact on receiving waters: a case study from Southwest England. Chemosphere 153, 294-306. doi: 10.1016/j.chemosphere.2016.03.022

Brouwers, G. J., de Vrind, J. P., Corstjens, P. L., Cornelis, P., Baysse, C., and de Vrind-de Jong, E. W. (1999). cumA, a gene encoding a multicopper oxidase, is involved in $\mathrm{Mn}^{2+}$ oxidation in Pseudomonas putida GB-1. Appl. Environ. Microbiol. 65, 1762-1768.

Brouwers, G. J., Vijgenboom, E., Corstjens, P. L. A. M., de Vrind, J. P. M., and de Vrind-de Jong, E. W. (2000). Bacterial $\mathrm{Mn}^{2+}$ oxidizing systems and multicopper oxidases: an overview of mechanisms and functions. Geomicrobiol. J. 17, 1-24. doi: 10.1080/014904500270459

Burger, M. S., Gagnon, G. A., Mercer, S. S., and Shupe, G. D. (2008). Manganese removal during bench-scale biofiltration. Water Res. 42, 4733-4742. doi: 10.1016/j.watres.2008.08.024

Chandra, R., Abhishek, A., and Sankhwar, M. (2011). Bacterial decolorization and detoxification of black liquor from rayon grade pulp manufacturing paper industry and detection of their metabolic products. Bioresour. Technol. 102, 6429-6436. doi: 10.1016/j.biortech.2011.03.048

Cycon, M., Zmijowska, A., Wojcik, M., and Piotrowska-Seget, Z. (2013). Biodegradation and bioremediation potential of diazinon-degrading Serratia marcescens to remove other organophosphorus pesticides from soils. J. Environ. Manage. 117, 7-16. doi: 10.1016/j.jenvman.2012.12.031

Das, A. P., Sukla, L. B., Pradhan, N., and Nayak, S. (2011). Manganese biomining: a review. Bioresour. Technol. 102, 7381-7387. doi: 10.1016/j.biortech.2011.05.018

Dick, G. J., Torpey, J. W., Beveridge, T. J., and Tebo, B. M. (2008). Direct identification of a bacterial manganese(II) oxidase, the multicopper oxidase MnxG, from spores of several different marine Bacillus species. Appl. Environ. Microbiol. 74, 1527-1534. doi: 10.1128/AEM.01240-07

Divekar, M. (2010). Isolation and Characterization of a Manganese Oxidizing Bacterium from the Mediterranean Marine Sponge Suberites domuncula. Doctoral dissertation Johannes Gutenberg-Universität, Mainz.

Ehrlich, H. L. (1999). Microbes as geologic agents: their role in mineral formation. Geomicrobiol. J. 16, 135-153. doi: 10.1080/014904599270659

Emerson, D., and Ghiorse, W. C. (1992). Isolation, cultural maintenance, and taxonomy of a sheath-forming strain of Leptothrix discophora and characterization of manganese-oxidizing activity associated with the sheath. Appl. Environ. Microbiol. 58, 4001-4010.

Gallard, H., and van Gunten, U. (2002). Chlorination of natural organic matter: kinetics of chlorination and of THM formation. Water Res. 36, 65-74. doi: 10.1016/S0043-1354(01)00187-7

Geszvain, K., McCarthy, J. K., and Tebo, B. M. (2013). Elimination of manganese(II,III) oxidation in Pseudomonas putida GB-1 by a double knockout of two putative multicopper oxidase genes. Appl. Environ. Microbiol. 79, 357-366. doi: 10.1128/AEM.01850- 12

Hope, C. K., and Bott, T. R. (2004). Laboratory modelling of manganese biofiltration using biofilms of Leptothrix discophora. Water Res. 38, 1853-1861. doi: 10.1016/j.watres.2003.12.031

Hullo, M. F., Moszer, I., Danchin, A., and Martin-Verstraete, I. (2001). CotA of Bacillus subtilis is a copper-dependent laccase. J. Bacteriol. 183, 5426-5430. doi: 10.1128/JB.183.18.5426-5430.2001

Imtiaz, M., Rizwan, M. S., Xiong, S., Li, H., Ashraf, M., Shahzad, S. M., et al. (2015). Vanadium, recent advancements and research prospects: a review. Environ. Int. 80, 79-88. doi: 10.1016/j.envint.2015.03.018

Instituto Brasileiro de Mineração [IBRAM] (2012). Informações e análises da Economia Mineral Brasileira, 7th Edn. Brasília: Instituto Brasileiro de Mineração [IBRAM].

Johnson, D. B., and Hallberg, K. B. (2003). The microbiology of acidic mine waters. Res. Microbiol. 154, 466-473. doi: 10.1016/S0923-2508(03)00114-1

Joshi, B. H., and Modi, K. G. (2013). Screening and characterization of heavy metal resistant bacteria for its prospects in bioremediation of contaminated soil. J. Environ. Res. Dev. 7, 1531-1538.
Klein, R., Tischler, J. S., Muhling, M., and Schlomann, M. (2014). Bioremediation of mine water. Adv. Biochem. Eng. Biotechnol. 141, 109-172. doi: 10.1007/10_ 2013_265

Krumbein, W. E., and Altmann, H. J. (1973). A new method for the detection and enumeration of manganese oxidizing and reducing microorganisms. Helgolander Wiss. Meeresunters 25, 347-356. doi: 10.1007/BF01611203

Kumar, R., Acharya, C., and Joshi, S. R. (2011). Isolation and analyses of uranium tolerant Serratia marcescens strains and their utilization for aerobic uranium U(VI) bioadsorption. J. Microbiol. 49, 568-574. doi: 10.1007/s12275-0110366-0

Learman, D. R., Wankel, S. D., Webb, S. M., Martinez, N., Madden, A. S., and Hansel, C. M. (2011). Coupled biotic-abiotic Mn(II) oxidation pathway mediates the formation and structural evolution of biogenic $\mathrm{Mn}$ oxides. Geochim. Cosmochim. Acta 75, 6048-6063. doi: 10.1016/j.gca.2011.07.026

Luan, F., Santelli, C. M., Hansel, C. M., and Burgos, W. D. (2012). Defining manganese(II) removal processes in passive coal mine drainage treatment systems through laboratory incubation experiments. Appl. Geochem. 27, 1567-1578. doi: 10.1016/j.apgeochem.2012.03.010

Mariner, R., Johnson, D. B., and Hallberg, K. B. (2008). Characterisation of an attenuation system for the remediation of $\mathrm{Mn}$ (II) contaminated waters. Hydromettallurgy 94, 100-104. doi: 10.1016/j.hydromet.2008.05.024

Massante, J. C. (2015). Mining disaster: restore habitats now. Nature 528:39. doi: $10.1038 / 528039$ c

Mayhew, L. E., Swanner, E. D., Martin, A. P., and Templeton, A. S. (2008). Phylogenetic relationships and functional genes: distribution of a gene ( $\mathrm{mnxG}$ ) encoding a putative manganese-oxidizing enzyme in Bacillus species. Appl. Environ. Microbiol. 74, 7265-7271. doi: 10.1128/AEM.00540-08

Miyata, N., Sugiyama, D., Tani, Y., Tsuno, H., Seyama, H., Sakata, M., et al. (2007). Production of biogenic manganese oxides by repeated-batch cultures of laboratory microcosms. J. Biosci. Bioeng. 103, 432-439. doi: 10.1263/jbb. 103.432

Nealson, K. H., Tebo, B. M., and Rosson, R. A. (1988). Occurrence and mechanisms of microbial oxidation of manganese. Adv. Appl. Microbiol. 33, 279-318. doi: 10.1016/S0065-2164(08)70209-0

Pacini, V. A., Ingallinella, A. M., and Sanguinetti, G. (2005). Removal of iron and manganese using biological roughing up flow filtration technology. Water Res. 39, 4463-4475. doi: 10.1016/j.watres.2005.08.027

Peres, T. V., Schettinger, M. R., Chen, P., Carvalho, F., Avila, D. S., Bowman, A. B., et al. (2016). Manganese-induced neurotoxicity: a review of its behavioral consequences and neuroprotective strategies. BMC Pharmacol. Toxicol. 17:57. doi: 10.1186/s40360-016-0099-0

Rajasekar, A., Babu, T. G., Pandian, S. T., Maruthamuthu, S., Palaniswamy, N., and Rajendran, A. (2007a). Role of Serratia marcescens ACE2 on diesel degradation and its influence on corrosion. J. Ind. Microbiol. Biotechnol. 34, 589-598. doi: 10.1007/s10295-007-0225-5

Rajasekar, A., Babu, T. G. B., Maruthamuthu, S., Pandian, S. T. K., Sidhan Mohanan, S. M., and Palaniswamy, N. (2007b). Biodegradation and corrosion behaviour of Serratia marcescens ACE2 isolated from an Indian dieseltransporting pipeline. World J. Microbiol. 23, 1065-1074. doi: 10.1007/s11274006-9332-0

Richardson, L. L., Aguilar, C., and Nealson, K. H. (1988). Manganese oxidation in $\mathrm{pH}$ and $\mathrm{O}_{2}$ microenvironments produced by phytoplankton. Limnol. Oceanogr. 33, 352-363. doi: 10.4319/lo.1988.33.3.0352

Saitou, N., and Nei, M. (1987). The neighbor-joining method: a new method for reconstructing phylogenetic trees. Mol. Biol. Evol. 4, 406-425.

SambrooK, J., Maniatis, T., and Fritsch, E. F. (1989). Molecular Cloning: A Laboratory Manual. Cold Spring Harbor, NY: Cold Spring Harbor Laboratory Press.

Sethurajan, M., Huguenot, D., Lens, P. N., Horn, H. A., Figueiredo, L. H., and van Hullebusch, E. D. (2016). Fractionation and leachability of heavy metals from aged and recent $\mathrm{Zn}$ metallurgical leach residues from the Tres Marias zinc plant (Minas Gerais, Brazil). Environ. Sci. Pollut. Res. 23, 7504-7516. doi: 10.1007/s11356-015-6014-1

Silva, A. M., Cruz, F. L., Lima, R. M., Teixeira, M. C., and Leao, V. A. (2010). Manganese and limestone interactions during mine water treatment. J. Hazard. Mater. 181, 514-520. doi: 10.1016/j.jhazmat.2010.05.044

Silva, A. M., Cunha, E. C., Silva, F. D. R., and Leão, V. A. (2012). Treatment of high-manganese mine water with limestone and sodium carbonate. J. Clean. Prod. 29-30, 11-19. doi: 10.1016/j.jclepro.2012.01.032 
Soldatova, A. V., Butterfield, C., Oyerinde, O. F., Tebo, B. M., and Spiro, T. G. (2012). Multicopper oxidase involvement in both $\mathrm{Mn}$ (II) and $\mathrm{Mn}$ (III) oxidation during bacterial formation of $\mathrm{MnO}_{2}$. J. Biol. Inorg. Chem. 17, 1151-1158. doi: 10.1007/s00775-012-0928-6

Su, J., Bao, P., Bai, T., Deng, L., Wu, H., Liu, F., et al. (2013). CotA, a multicopper oxidase from Bacillus pumilus WH4, exhibits manganese-oxidase activity. PLOS ONE 8:e60573. doi: 10.1371/journal.pone.0060573

Tang, W., Gong, J., Wu, L., Li, Y., Zhang, M., and Zeng, X. (2016). DGGE diversity of manganese mine samples and isolation of a Lysinibacillus $\mathrm{sp}$. efficient in removal of high Mn (II) concentrations. Chemosphere 165, 277-283. doi: 10.1016/j.chemosphere.2016.08.134

Tebo, B. M., Bargar, J. R., Clement, B. G., Dick, G. J., Murray, K. J., Parker, D., et al. (2004). Biogenic manganese oxides: properties and mechanisms of formation. Annu. Rev. Earth Planet. Sci. 32, 287-328. doi: 10.1146/annurev.earth.32. 101802.120213

Tebo, B. M., Johnson, H. A., McCarthy, J. K., and Templeton, A. S. (2005). Geomicrobiology of manganese(II) oxidation. Trends Microbiol. 13, 421-428. doi: 10.1016/j.tim.2005.07.009

Tuffin, I. M., Hector, S. B., Deane, S. M., and Rawlings, D. E. (2006). Resistance determinants of a highly arsenic-resistant strain of Leptospirillum ferriphilum isolated from a commercial biooxidation tank. Appl. Environ. Microbiol. 72, 2247-2253. doi: 10.1128/AEM.72.3.2247-2253.2006

van Waasbergen, L. G., Hildebrand, M., and Tebo, B. (1996). Identification and characterization of a gene cluster involved in manganese oxidation by spore of marine Bacillus sp strain SG-1. J. Bacteriol. 178, 3517-3530. doi: 10.1128/jb.178. 12.3517-3530.1996
Verma, P., and Madamwar, D. (2003). Decolourization of synthetic dyes by a newly isolated strain of Serratia marcescens. World J. Microbiol. Biotechnol. 19, 615-618. doi: 10.1023/A:1025115801331

Wang, J., Yang, D., Zhang, Y., Shen, J., van der Gast, C., Hahn, M. W., et al. (2011). Do patterns of bacterial diversity along salinity gradients differ from those observed for macroorganisms? PLOS ONE 6:e27597. doi: 10.1371/journal. pone.0027597

Xuezheng, L., Aiguo, G., and Haowen, C. (2008). Isolation and phylogenetic analysis of cultivable manganese bacteria in sediments from The Arctic Ocean. Acta Ecol. Sin. 28, 6364-6370. doi: 10.1016/S1872-2032(09)60017-2

Yang, W., Zhang, Z., Chen, H., Liu, J., Ali, M., Liu, F., et al. (2013). Population structure of manganese-oxidizing bacteria in stratified soils and properties of manganese oxide aggregates under manganese-complex medium enrichment. PLOS ONE 8:e73778. doi: 10.1371/journal.pone.0073778

Conflict of Interest Statement: The authors declare that the research was conducted in the absence of any commercial or financial relationships that could be construed as a potential conflict of interest.

Copyright (C) 2017 Barboza, Morais, Queiroz, Amorim, Guerra-Sá and Leão. This is an open-access article distributed under the terms of the Creative Commons Attribution License (CC BY). The use, distribution or reproduction in other forums is permitted, provided the original author(s) or licensor are credited and that the original publication in this journal is cited, in accordance with accepted academic practice. No use, distribution or reproduction is permitted which does not comply with these terms. 